Article

\title{
Novel Purification Process for Amyloid Beta Peptide(1-40)
}

\author{
Kenji Usui ${ }^{*}{ }^{\dagger}$, Shin-ichiro Yokota ${ }^{\dagger}$, Kazuya Iwata and Yoshio Hamada ${ }^{*}$ \\ Faculty of Frontiers of Innovative Research in Science and Technology (FIRST), Konan University, Chuo-ku, \\ Kobe 650-0047, Japan; m1861013@a.konan-u.ac.jp (S.-i.Y.); s1791005@s.konan-u.ac.jp (K.I.) \\ * Correspondence: kusui@konan-u.ac.jp (K.U.); pynden@gmail.com (Y.H.) \\ + These authors contributed equally to this work.
}

Received: 12 March 2020; Accepted: 8 April 2020; Published: 15 April 2020

\begin{abstract}
Amyloid beta peptide (A $\beta$ )-related studies require an adequate supply of purified $A \beta$ peptide. However, A $\beta$ peptides are "difficult sequences" to synthesize chemically, and low yields are common due to aggregation during purification. Here, we demonstrate an easier synthesis, deprotection, reduction, cleavage, and purification process for $\mathrm{A} \beta(1-40)$ using standard 9-fluorenylmethyloxycarbonyl (Fmoc)-protected amino acids and solid-phase peptide synthesis (SPPS) resin [HMBA (4-hydroxymethyl benzamide) resin] that provides higher yields of $A \beta(1-40)$ than previous standard protocols. Furthermore, purification requires a similar amount of time as conventional purification processes, although the peptide must be cleaved from the resin immediately prior to purification. The method described herein is not limited to the production of $A \beta(1-40)$, and can be used to synthesize other easily-oxidized and aggregating sequences. Our proposed methodology will contribute to various fields using "difficult sequence" peptides, such as pharmaceutical and materials science, as well as research for the diagnosis and treatment of protein/peptide misfolding diseases.
\end{abstract}

Keywords: peptide synthesis; reduction; purification; amyloid beta peptide; solid-phase synthesis; difficult sequence; aggregating peptide

\section{Introduction}

Protein misfolding diseases are increasingly common in aging populations and include Alzheimer's disease, Parkinson's disease, and Huntington's disease. These diseases involve the systematic or tissue-localized deposition of fibrillar, $\beta$-sheet-rich protein/peptide assemblies [1,2]. In Alzheimer's disease (AD) $[3,4]$, amyloid beta peptide $(\mathrm{A} \beta)$ forms fibrillar aggregates known as amyloid fibrils $[5,6]$, which are the principal component of extracellular deposits and are the likely causative agent of AD. Many scientists have investigated $A \beta$ aggregation, but the mechanism by which $A \beta$ aggregates in vivo, and how the generated aggregates affect disease development, remains unknown. Recent studies have implicated $A \beta$ and its ability to self-assemble as key factors in the pathogenesis of AD. A $\beta$-related studies require an adequate supply of purified A $\beta$ peptide. However, $\mathrm{A} \beta$ peptides are "difficult sequences" to synthesize chemically, and low yields are common due to aggregation during purification [7-10]. To address this, Mutter et al. developed pseudoproline building blocks that are dipeptide derivatives containing serine (Ser)/threonine (Thr)-derived oxazolidines or cysteine (Cys)-derived thiazolidine [11]. Sheppard et al. also reported a building block, 2-hydroxy-4-methoxybenzyl ( $\mathrm{Hmb})$, as a protecting group for the backbone amide nitrogen [12]; Martin et al. optimized and applied this method to $\mathrm{A} \beta(1-43)$ [13]; and very recently Kasim et al. used $\mathrm{Hmb}$ as a linker for preparation of $\mathrm{A} \beta(1-42)$ [14]. Sohma et al. developed a method involving the $\mathrm{O}-\mathrm{N}$ intramolecular acyl migration reaction of O-acyl isopeptides. O-acyl isopeptides improve both peptide solubility in various media and the nature 
of the difficult sequence during solid-phase peptide synthesis (SPPS) [15-17]. All these innovative studies provided efficient strategies towards the synthesis of amyloid beta peptide, but an easy, simple, low-cost, and versatile method is still needed.

Here, we demonstrate an easier synthesis, deprotection, reduction, cleavage, and purification process for $A \beta(1-40)$ using standard 9-fluorenylmethyloxycarbonyl (Fmoc)-protected amino acids and SPPS resin that provides higher yields of $A \beta(1-40)$ than previous standard protocols (Figure 1). This process is applicable not only to the $A \beta(1-40)$ sequence but also to other easily oxidized, aggregating sequences. Our proposed methodology will contribute to various fields using "difficult sequence" peptides, such as pharmaceutical and materials science, as well as research for the diagnosis and treatment of protein/peptide misfolding diseases.

\section{1) Peptide synthesis using HMBA resin}

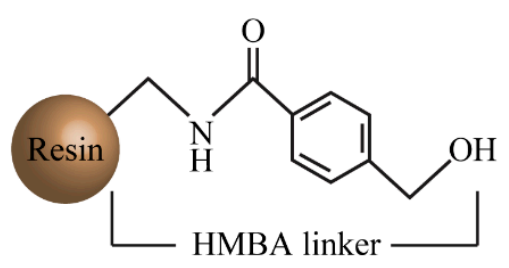

HMBA resin
SPPS using standard Fmoc-AA-OH

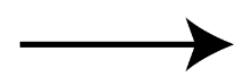

$\odot \mathrm{H}_{\mathrm{H}}$

Protected peptide

\section{2) Deprotection and reduction on HMBA resin}

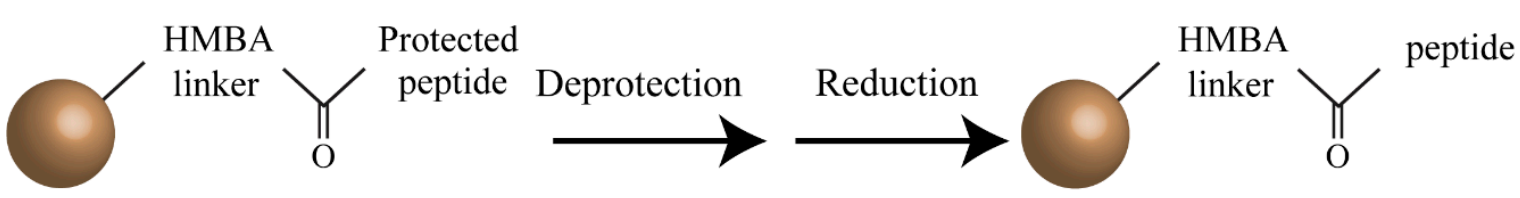

\section{3) Cleavage of peptide from HMBA resin}

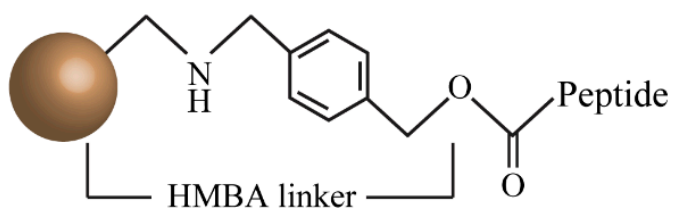

Treating with

$\mathrm{NaOH}$<smiles>O=C(NCC1CCCCCC1)c1ccc(CO)cc1</smiles>

$\prod_{\mathrm{O}}^{\mathrm{HO}} \stackrel{\text { Peptide }}{\stackrel{\text { Purification }}{\longrightarrow}}$

Figure 1. Scheme of the peptide synthesis, deprotection, reduction, cleavage, and purification process. 1) After attaching the first amino acid to 4-hydroxymethyl benzamide (HMBA) resin by standard ester coupling, standard Fmoc peptide synthesis was conducted using the (HBTU)-1-hydroxy benzotriazole monohydrate (HOBt) method. 2) Deprotection of all of the side-chain-protected peptide was conducted using the standard trifluoroacetic acid (TFA) method. Then some oxidized peptides were reduced using $\mathrm{NH}_{4} \mathrm{I}$ and dimethyl sulfide (DMS). 3) Cleavage of the peptide from HMBA resin using $500 \mathrm{mM}$ $\mathrm{NaOH}$ and acetonitrile $(1 / 1, \mathrm{v} / \mathrm{v})$.

\section{Results and Discussion}

\subsection{Fmoc Peptide Synthesis Using HMBA-Resin}

We selected HMBA (4-hydroxymethyl benzamide) resin [18]. HMBA is a commonly used base-labile linker that allows the deprotection of the peptide with TFA without cleaving the peptide 
from the resin. This allows the deprotected peptide to subsequently be cleaved quickly using a low concentration of aqueous base. The purity of the cleaved peptide is usually very high, and purification is frequently not required prior to characterization and use. $A \beta(1-40)$ easily aggregates in acidic conditions but remains monomeric or oligomeric in basic conditions. A NaOH-based protocol for the preparation of $A \beta(1-40)$ monomer was recently reported and has been widely adapted [19]. We thus used aqueous $\mathrm{NaOH}$ to both cleave $\mathrm{A} \beta(1-40)$ from the resin and keep it monomeric, allowing facile purification.

After attaching the first amino acid (valine) to HMBA resin by standard ester coupling, Fmoc peptide synthesis was conducted using the (2-(1H-benzotriazole-1-yl)-1,1,3,3-tetramethyluronium hexafluorophosphate) (HBTU)-1-hydroxy benzotriazole monohydrate (HOBt) method (10 eq., double coupling, see Section 3.2) (Figure 1). Although we adopted this method in order to synthesize the peptides certainly, we must improve the conditions such as equivalents in future studies. Following synthesis, the peptide was deprotected using the standard TFA method (see Section 3.3), then the peptide was cleaved with aqueous $\mathrm{NaOH} /$ acetonitrile $(1 / 1, \mathrm{v} / \mathrm{v})$. Acetonitrile is required to prevent nonspecific adsorption of $A \beta(1-40)$ to the resin, thus providing higher yields (see Section 3.4). Peptide purity was checked by high performance liquid chromatography (HPLC) and matrix assisted laser desorption ionization (MALDI) - time of flight (TOF) mass spectrometry (MS) (see Section 3.6). The HPLC chart showed two main peaks, reduced $A \beta(1-40)$ and oxidized $A \beta(1-40)$, indicating that the methionine of $A \beta(1-40)$ is partially oxidized to methionine sulfoxide during synthesis and deprotection (Figure 2a). The $\mathrm{NaOH}$ cleavage and monomerization method using HMBA resin was much easier than a conventional method using Wang resin (Figure S2), which needed a monomerization step using guanidine hydrochloride ( $\mathrm{GdnHCl}$ ) (see Section S1.3 in SI). The $\mathrm{GdnHCl}$ monomerization step takes 1 day, and $\mathrm{GdnHCl}$ can damage an HPLC column. Peptide reduction before cleavage is thus indispensable for obtaining higher yields of $A \beta(1-40)$ in our method.
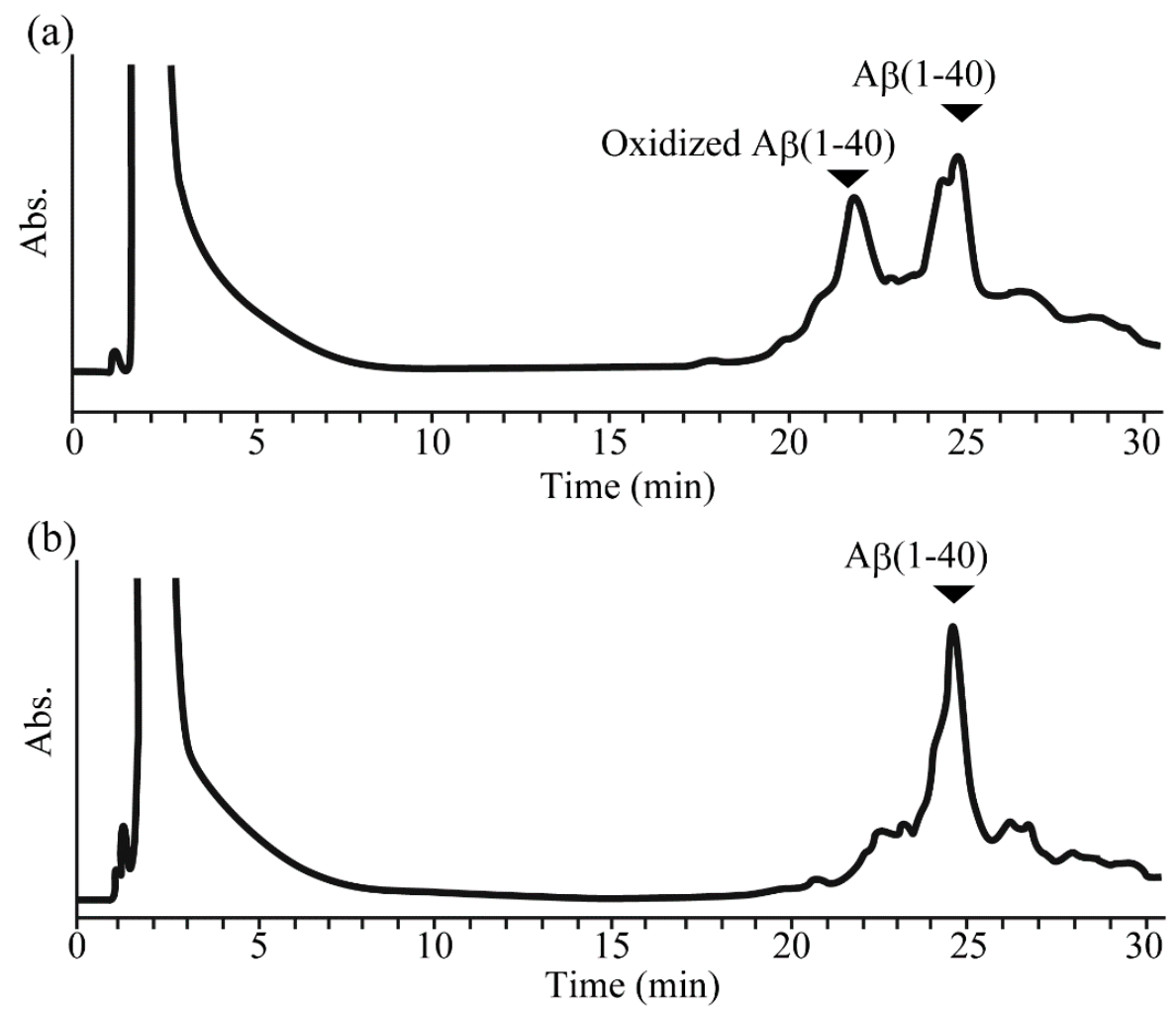

Figure 2. (a) HPLC chart of the cleaved $A \beta(1-40)$ from HMBA resin without the reduction process. (b) HPLC chart of the cleaved A $\beta$ (1-40) from HMBA resin with the reduction process. The peaks were characterized by MALDI-TOF MS: the oxidized A $\beta(1-40), \mathrm{m} / \mathrm{z} 4346.9\left((\mathrm{M}+\mathrm{H})^{+}\right.$calcd. 4346.6$) ; \mathrm{A} \beta(1-40)$, $\mathrm{m} / \mathrm{z} 4330.8\left((\mathrm{M}+\mathrm{H})^{+}\right.$calcd. 4330.6). 


\subsection{Reduction of Oxidized $A \beta(1-40)$ and $A \beta(17-40)$ on the Resin}

We reduced methionine sulfoxide [20] after the deprotection step (Figure 1, see Section 3.5). $\mathrm{NH}_{4} \mathrm{I}$ (30 eq.) and dimethyl sulfide (DMS, 30 eq.) in TFA/Milli-Q (7/3, v/v) were added to an ice-cooled column containing deprotected peptidyl resin. Keeping the column at $0{ }^{\circ} \mathrm{C}$ with ice, a half-volume of mercaptoacetic acid (TFA-Milli-Q/mercaptoacetic acid $=2 / 1, \mathrm{v} / \mathrm{v}$ ) was added, which was indispensable for preventing from the generation of histidine iodide (Figure S1). After $30 \mathrm{~min}$ at $0{ }^{\circ} \mathrm{C}$, the peptide was cleaved from the resin (see Section 3.4). The purity of the peptide was checked by HPLC and MS (see Section 3.6). The HPLC chart showed one main peak, corresponding to reduced A $\beta(1-40)$, indicating that this reduction step was successful and efficiently provided a higher yield of the target peptide $A \beta(1-40)$ (Figure $2 b$ ).

In addition, we also demonstrated the reduction of a sequence without histidine, $A \beta(17-40)$ (Figure 3a, see Section 3.5). In this case, the addition of mercaptoacetic acid was not necessary. The reduction of $A \beta(17-40)$ without this step was conducted. The HPLC chart (see Section 3.6) showed one main peak, corresponding to reduced $A \beta(17-40)$, indicating that this reduction step was successful and efficiently provided a higher yield of the target peptide $A \beta(17-40)$ (Figure $3 b)$.
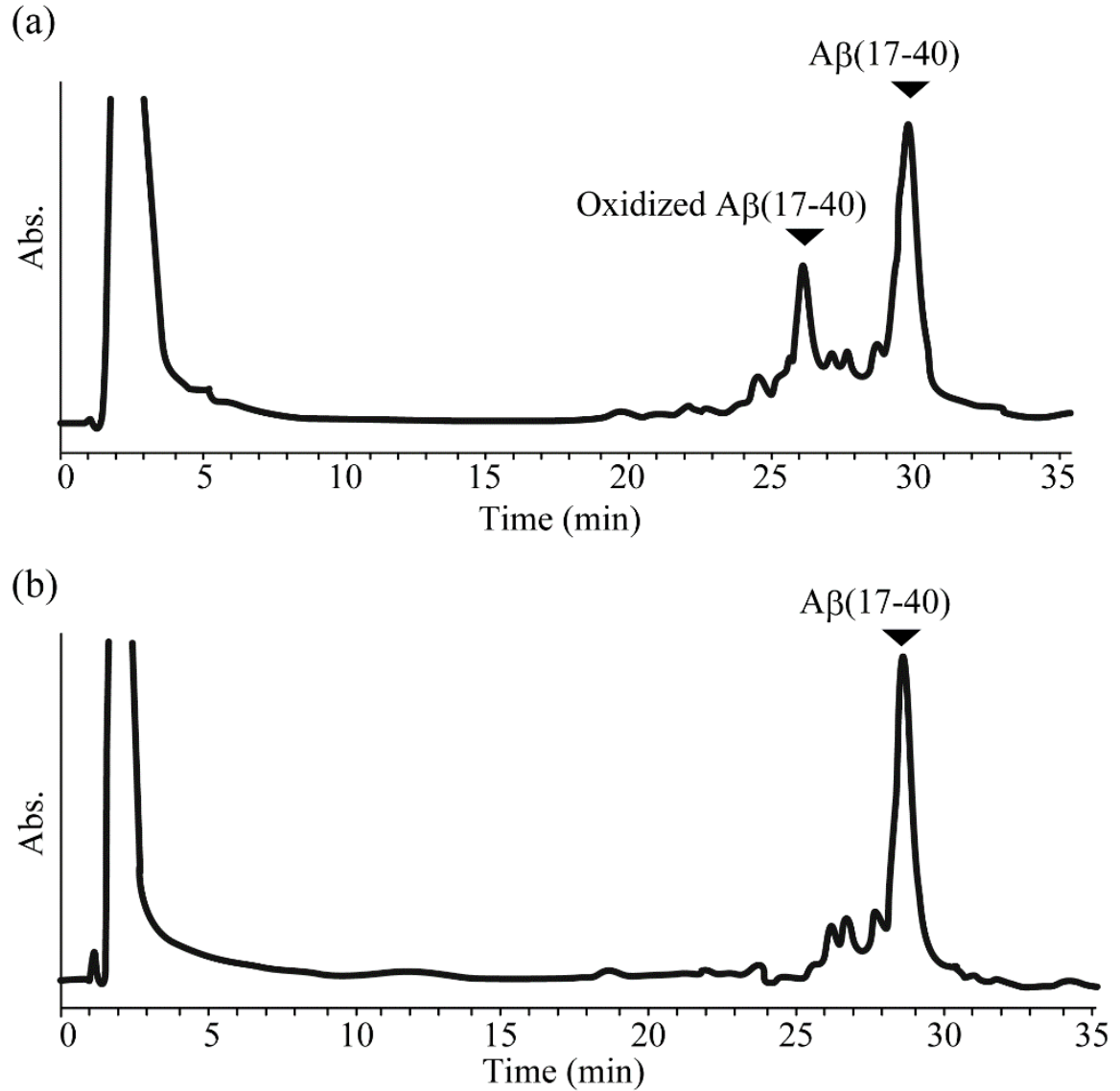

Figure 3. (a) HPLC chart of the cleaved $A \beta(17-40)$ from HMBA resin without the reduction process. (b) HPLC chart of the cleaved $A \beta(17-40)$ from HMBA resin with the reduction process not using mercaptoacetic acid. The peaks were characterized by MALDI-TOF MS: the oxidized A $\beta(17-40), \mathrm{m} / \mathrm{z}$ $2409.9\left((\mathrm{M}+\mathrm{H})^{+}\right.$calcd. 2409.7); A $\beta(17-40), \mathrm{m} / \mathrm{z} 2393.6\left((\mathrm{M}+\mathrm{H})^{+}\right.$calcd. 2393.7).

\subsection{ThT Assay of AB (1-40) Cleaved from HMBA Resin}

We checked if $A \beta(1-40)$ aggregated after cleavage by fluorescence measurements using thioflavin $\mathrm{T}$ (ThT) (Figure 4) (see Section 3.7). ThT fluorescence originates only from binding to amyloid fibrils. It is widely assumed that the fluorescent increase of ThT is due to the selective immobilization of 
a subset of ThT conformers [21]. The fluorescence intensity of ThT did not increase after cleavage, whereas the sample of dissolved $A \beta(1-40)$ powder with $250 \mathrm{mM} \mathrm{NaOH}$ for monomerization showed higher fluorescence intensity of ThT than that after cleavage from HMBA resin with $\mathrm{NaOH}$ by our method. These results indicated that $A \beta(1-40)$ was completely monomerized on the HMBA resin, and that $A \beta(1-40)$ aggregation was inhibited by the basic conditions. This suggests that purification would be easier under basic rather than standard acidic cleavage conditions.

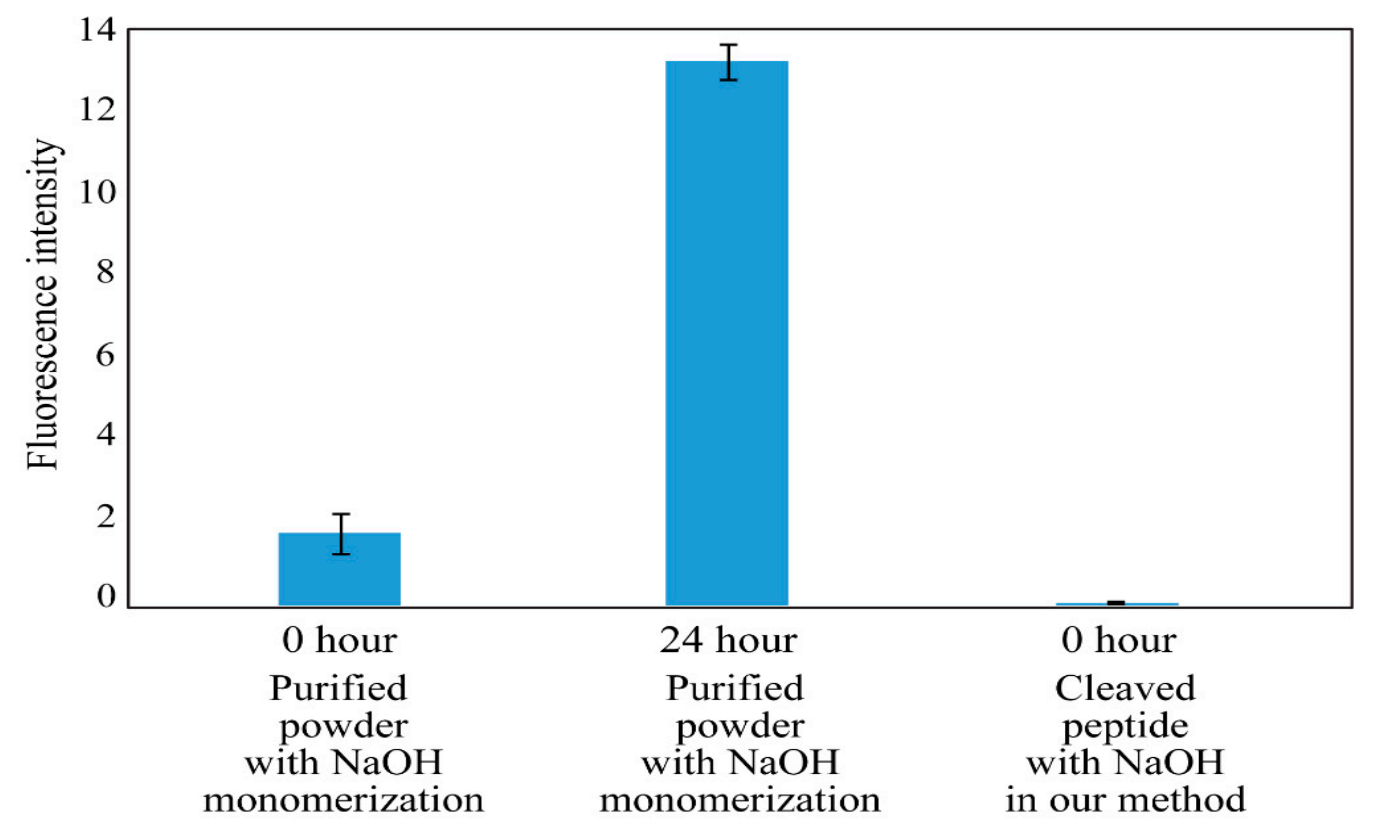

Figure 4. Thioflavin $\mathrm{T}$ (ThT) assay with $\mathrm{A} \beta(1-40)$ sample, $0 \mathrm{~h}$ or $24 \mathrm{~h}$ after preparation by dissolving the lyophilized powder in $250 \mathrm{mM} \mathrm{NaOH}$ for monomerization, and $0 \mathrm{~h}$ after cleavage from HMBA resin with $\mathrm{NaOH}$ by our method.

\subsection{Optimization of the Purification Process of $A \beta(1-40)$}

We then optimized the purification protocol to obtain higher yields and facilitate handling. Following peptide synthesis, an aliquot of the resin was deprotected, reduced, cleaved, and immediately purified (Figure 1). After deprotection and reduction, resin sufficient for one HPLC injection was cleaved in a $1.5 \mathrm{~mL}$ tube to prevent $\mathrm{A} \beta$ aggregation. Cleavage required $20 \mathrm{~min}$, and thus the cleaved crude peptide solution was ready for injection on the HPLC (see Section 3.8) as soon as the previous injection of peptide had eluted from the C-18 column. The optimized batch purification process took a similar amount of time as the conventional purification process, although each injection required a separate cleavage step. In our method, the total yield was $3.6 \%$ despite a small scale in this time, and we could not purify the sample cleaved from the Wang resin because it was hard to separate the second peak completely. Additionally, the $\mathrm{NaOH}$ cleavage and monomerization method using HMBA resin was much easier than the conventional method using Wang resin, which needed a 1-day monomerization step using $\mathrm{GdnHCl}$, which can damage a column. Thus, our methodology would offer easier handling and obtain higher yields of $A \beta(1-40)$ than previous standard methodology.

\section{Materials and Methods}

\subsection{Materials}

All chemicals were used without further purification. The peptides were characterized by MALDI-TOF MS on an Autoflex III mass spectrometer (Bruker Daltonics, Billerica, MA, USA) using 3,5-dimethoxy-4-hydroxycinnamic acid as the matrix. 


\subsection{Fmoc Peptide Synthesis of $A \beta(1-40)$ and $A \beta(17-40)$ Using HMBA Resin}

$A \beta(1-40)$ and $A \beta(17-40)$ peptides were synthesized using HMBA (4-hydroxymethyl benzamide)-PEG resin (HiPep Laboratories Co., Ltd., Kyoto, Japan) by Fmoc solid-phase synthesis [22] using the (2-(1H-benzotriazole-1-yl)-1,1,3,3-tetramethyluronium hexafluorophosphate) (HBTU)-1-hydroxy benzotriazole monohydrate (HOBt) method (10 eq., double coupling). The DIPCI ( $N, N^{\prime}$-Diisopropylcarbodiimide) - DMAP ( $N, N$-dimethyl-4-aminopyridine) method was used for the first residue (valine). The side-chain-protecting groups used were t-butyloxy carbonyl (Boc) for Lys; 2,2,4,6,7-pentamethyldihydrobenzofuran-5-sulfonyl (Pbf) for arginine (Arg); t-butyl (tBu) for serine (Ser), tyrosine (Tyr), aspartic acid (Asp), and glutamic acid (Glu); and trityl (Trt) for histidine (His), asparagine (Asn), and glutamine (Gln).

\subsection{Deprotection of $A \beta(1-40)$ and $A \beta(17-40)$ Using $H M B A$ Resin}

The side-chain-protecting groups on the resins were removed by incubating the peptide-resin for $2 \mathrm{~h}$ in deprotection solution (trifluoroacetic acid (TFA)/triisopropylsilane/water $(90 / 5 / 5, \mathrm{v} / \mathrm{v})$ ). The resin was washed 5 times with the deprotection solution and chloroform, and then the resins were dried completely in a desiccator. The peptide-resin was stored at $4{ }^{\circ} \mathrm{C}$.

\subsection{Cleavage of $A \beta(1-40)$ and $A \beta(17-40)$ from $H M B A$ Resin}

When the peptide-resin was dried, the resin was swelled by acetonitrile overnight. The swelled resin was treated with $500 \mathrm{mM} \mathrm{NaOH}$ and acetonitrile $(1 / 1, \mathrm{v} / \mathrm{v})$ for $20 \mathrm{~min}$ at room temperature.

\subsection{Reduction of Oxidized $A \beta(1-40)$ and $A \beta(17-40)$ on the Resin}

In the case of $A \beta(1-40)$, the peptide-resin was incubated in TFA/Milli-Q $(7 / 3, \mathrm{v} / \mathrm{v})$ with DMS (30 eq.) and $\mathrm{NH}_{4} \mathrm{I}$ (30 eq.) with ice cooling at $0{ }^{\circ} \mathrm{C}$. Keeping the column at $0{ }^{\circ} \mathrm{C}$ with ice, a half-volume of mercaptoacetic acid (TFA-Milli-Q/mercaptoacetic acid $=2 / 1, \mathrm{v} / \mathrm{v}$ ) was added to the reaction solution, and the resin was incubated for $30 \mathrm{~min}$ at $0{ }^{\circ} \mathrm{C}$. After the reduction reaction, the resin was washed 10 times with TFA and Milli-Q.

In the case of $A \beta(17-40)$, the peptide-resin was incubated in TFA/Milli-Q $(7 / 3, v / v)$ with DMS (30 eq.) and $\mathrm{NH}_{4} \mathrm{I}\left(30\right.$ eq.) with ice cooling at $0{ }^{\circ} \mathrm{C}$. The resin was incubated for $30 \mathrm{~min}$ at $0{ }^{\circ} \mathrm{C}$. After the reduction reaction, the resin was washed 10 times with TFA and Milli-Q.

\subsection{Analysis of $A \beta(1-40)$ and $A \beta(17-40)$}

The HPLC was performed on the GL7410 pump and GL7450 detector system (GL Sciences Inc., Tokyo, Japan) using $220 \mathrm{~nm}$ absorbance. A $\beta(1-40)$ was analyzed on a Shodex Asahipak ODS-50 column $(4.5 \times 150 \mathrm{~mm}$, Showa Denko K.K., Tokyo, Japan) using an isocratic condition with $100 \%$ of A solvent over $5 \mathrm{~min}$ and then a linear gradient from $0 \%$ to $25 \%$ of B solvent $(90 \%$ acetonitrile, $10 \%$ Milli-Q, and $0.1 \% \mathrm{NH}_{4} \mathrm{OH}$ ) over $25 \mathrm{~min}$ at a flow rate of $1.0 \mathrm{~mL} / \mathrm{min}$. $\mathrm{A} \beta(17-40)$ was analyzed on a Shodex Asahipak ODS-50 column $(4.5 \times 150 \mathrm{~mm}$, Showa Denko K.K) using an isocratic condition with $100 \%$ of A solvent over $5 \mathrm{~min}$, and then a linear gradient from $0 \%$ to $30 \%$ of B solvent $(90 \%$ acetonitrile, $10 \%$ Milli-Q and $0.1 \% \mathrm{NH}_{4} \mathrm{OH}$ ) over $30 \mathrm{~min}$ at a flow rate of $1.0 \mathrm{~mL} / \mathrm{min}$.

\subsection{Thioflavin T (ThT) Fluorescence Assay}

Samples $(20 \mu \mathrm{L})$ were diluted in phosphate buffer (final concentration: $50 \mathrm{mM}$ sodium phosphate and $300 \mathrm{mM} \mathrm{NaCl}, \mathrm{pH} 7.5$ ) containing ThT (final concentration: $25 \mu \mathrm{M}$, total volume $100 \mu \mathrm{L}$ ), and fluorescence was measured (excitation at $450 \mathrm{~nm}$, emission at $492 \mathrm{~nm}$ ) using a fluorescence microplate reader (MTP-601, Corona Electric Co., Ltd., Hitachinaka, Japan) [8]. 


\subsection{Purification of $A \beta(1-40)$}

The HPLC was performed on the GL7410 pump and GL7450 detector system (GL Sciences) using $220 \mathrm{~nm}$ absorbance. After the reduction (see Section 3.5), the peptide was purified on a Shodex Asahipak ODS-50 column $(10 \times 250 \mathrm{~mm}$ for purification, Showa Denko K.K) using an isocratic condition with $100 \%$ of A solvent over $5 \mathrm{~min}$, and then using a linear gradient from $0 \%$ to $30 \%$ of $\mathrm{B}$ solvent (90\% acetonitrile, $10 \%$ Milli-Q and $0.1 \% \mathrm{NH}_{4} \mathrm{OH}$ ) over $30 \mathrm{~min}$ at a flow rate of $3.0 \mathrm{~mL} / \mathrm{min}$.

\section{Conclusions}

We demonstrated easier synthesis, deprotection, reduction, cleavage, and purification processes for $A \beta(1-40)$ using standard Fmoc-protected amino acids and a common SPPS resin, HMBA resin. In our process, we could use aqueous $\mathrm{NaOH}$ to both cleave $A \beta(1-40)$ from the resin and keep it monomeric, allowing facile purification. Thus, our methodology provided higher yields of $A \beta(1-40)$ than previous standard protocols. Additionally, the optimized purification process took a similar amount of time as the conventional purification process, although the peptide must be cleaved from the resin immediately prior to purification. The method described herein is not limited to the production of $A \beta(1-40)$, and can be used to synthesize other easily-oxidized and aggregating sequences. Our proposed methodology will contribute to various fields using "difficult sequence" peptides, such as pharmaceutical and materials science, as well as research for the diagnosis and treatment of protein/peptide misfolding diseases.

Supplementary Materials: The following are available online at http://www.mdpi.com/2227-9717/8/4/464/s1, the additional materials and methods, Figure S1: HPLC chart of A $\beta(1-40)$ cleaved from HMBA resin after the reduction process without mercaptoacetic acid, Figure S2: HPLC chart of A $\beta(1-40)$ by conventional peptide synthesis using wang resin.

Author Contributions: Conceptualization, K.U. and Y.H.; methodology, K.I., S.-i.Y. and Y.H.; writing—original draft preparation, K.U. and S.-i.Y.; writing-review and editing, K.U., S.-i.Y. and Y.H. All authors have read and agreed to the published version of the manuscript.

Funding: This research was funded by The Nipponham Foundation for the Future of Food (NFFF), and KU is grateful for KAKENHI Grant Number 19K05741 from the Japan Society for the Promotion of Science (JSPS).

Conflicts of Interest: The authors declare no conflict of interest.

\section{References}

1. Knowles, T.P.; Vendruscolo, M.; Dobson, C.M. The amyloid state and its association with protein misfolding diseases. Nat. Rev. Mol. Cell. Biol. 2014, 15, 384-396. [CrossRef] [PubMed]

2. Kelly, J.W. Alternative conformations of amyloidogenic proteins govern their behavior. Curr. Opin. Struct. Biol. 1996, 6, 11-17. [CrossRef]

3. George, G.G. Alzheimer's disease: Its proteins and genes. Cell 1988, 52, 307-308.

4. Tanzi, R.E.; Bertram, L. Twenty years of the Alzheimer's disease amyloid hypothesis: A genetic perspective. Cell 2005, 120, 545-555. [CrossRef]

5. Hamley, I.W. The amyloid beta peptide: A chemist's perspective. Role in Alzheimer's and fibrillization. Chem. Rev. 2012, 12, 5147-5192. [CrossRef]

6. Changiz, G.; Wu, C.-K.; Daniel, S.; Alfredo, L.; Menglan, Y.; Bruce, A.Y. Aging renders the brain vulnerable to amyloid $\beta$-protein neurotoxicity. Nat. Med. 1998, 4, 827-831.

7. Tickler, A.K.; Clippingdale, A.B.; Wade, J.D. Amyloid-beta as a "difficult sequence" in solid phase peptide synthesis. Protein. Pept. Lett. 2004, 11, 377-384. [CrossRef]

8. Usui, K.; Hulleman, J.D.; Paulsson, J.F.; Siegel, S.J.; Powers, E.T.; Kelly, J.W. Site-specific modification of Alzheimer's peptides by cholesterol oxidation products enhances aggregation energetics and neurotoxicity. Proc. Natl. Acad. Sci. USA 2009, 106, 18563-18568. [CrossRef]

9. Zarándi, M.; Soós, K.; Fülöp, L.; Bozsó, Z.; Datki, Z.; Tóth, G.K.; Penke, B. Synthesis of Abeta [1-42] and its derivatives with improved efficiency. J. Pept. Sci. 2007, 13, 94-99. [CrossRef] 
10. Usui, K.; Mie, M.; Andou, T.; Mihara, H.; Kobatake, E. Fluorescent and luminescent fusion proteins for analyses of amyloid beta peptide aggregation. J. Pept. Sci. 2017, 23, 659-665. [CrossRef]

11. Guichou, J.-F.; Patiny, L.M. Mutter. Pseudo-prolines (Psi Pro): Direct insertion of Psi Pro systems into cysteine containing peptides. Tetrahedron Lett. 2002, 43, 4389-4390. [CrossRef]

12. Johnson, T.; Quibell, M.; Sheppard, R.C. N,O-bisFmoc derivatives of N-(2-hydroxy-4-methoxybenzyl)-amino acids: Useful intermediates in peptide synthesis. J. Pept. Sci. 1995, 1, 11-25. [CrossRef] [PubMed]

13. Martin, Q.; William, G.T.; Tony, J. Improved preparation of $\beta$-amyloid(1-43): Structural insight leading to optimised positioning of N-(2-hydroxy-4-methoxybenzyl)(Hmb) backbone amide protection. J. Chem. Soc. Perkin Trans. 1995, 1, 2019-2024.

14. Kasim, J.K.; Kavianinia, I.; Ng, J.; Harris, P.W.R.; Birch, N.P.; Brimble, M.A. Efficient synthesis and characterisation of the amyloid beta peptide, A $\beta 1-42$, using a double linker system. Org. Biomol. Chem. 2018, 17, 30-34. [CrossRef]

15. Sohma, Y.; Sasaki, M.; Hayashi, Y.; Kimura, T.; Kiso, Y. Novel and efficient synthesis of difficult sequence-containing peptides through $\mathrm{O}-\mathrm{N}$ intramolecular acyl migration reaction of $\mathrm{O}$-acyl isopeptides. Chem. Commun. 2004, 124-125. [CrossRef]

16. Sohma, Y.; Hayashi, Y.; Skwarczynski, M.; Hamada, Y.; Sasaki, M.; Kimura, T.; Kiso, Y. O-N intramolecular acyl migration reaction in the development of prodrugs and the synthesis of difficult sequence-containing bioactive peptides. Biopolymers 2004, 76, 344-356. [CrossRef]

17. Sohma, Y.; Sasaki, M.; Hayashi, Y.; Kimura, T.; Kiso, Y. Design and synthesis of a novel water-soluble A $\beta 1-42$ isopeptide: An efficient strategy for the preparation of Alzheimer's disease-related peptide, A $\beta 1-42$, via $\mathrm{O}-\mathrm{N}$ intramolecular acyl migration reaction. Tetrahedron Lett. 2004, 45, 5965-5968. [CrossRef]

18. Hansen, J.; Diness, F.; Meldal, M. C-Terminally modified peptides via cleavage of the HMBA linker by O-, Nor S-nucleophiles. Org. Biomol. Chem. 2016, 14, 3238-3245. [CrossRef]

19. Fezoui, Y.; Hartley, D.M.; Harper, J.D.; Khurana, R.; Walsh, D.M.; Condron, M.M.; Selkoe, D.J.; Lansbury, P.T., Jr.; Fink, A.L.; Teplow, D.B. An improved method of preparing the amyloid beta-protein for fibrillogenesis and neurotoxicity experiments. Amyloid 2000, 7, 166-178. [CrossRef]

20. Marta, V.; Ernesto, N.; Fina, C.; Ernest, G. Reduction of methionine sulfoxide with $\mathrm{NH}_{4} \mathrm{I} / \mathrm{TFA}$ : Compatibility with peptides containing cysteine and aromatic amino acids. Tetrahedron 1998, 54, 15273-15286.

21. Biancalana, M.; Koide, S. Molecular mechanism of thioflavin-T binding to amyloid fibrils. Biochim. Biophys. Acta. 2010, 1804, 1405-1412. [CrossRef] [PubMed]

22. Chan, W.C.; White, P.D. Fmoc Solid Phase Peptide Synthesis; Oxford University Press: New York, NY, USA, 2000. 